clung to the antiquated conceptions which his own experiments had really overthrown. In this connection Sir Edward Thorpe has emphasised the striking contrast between Priestley the social, political, and theological reformer, always in advance of his time, and Priestley the conservative and orthodox man of science.

Sir Edward holds that, great as was Priestley's merit as an experimentalist, a greater claim to our regard rests on his struggles and sufferings in the cause of liberty. Unpopularity and even persecution were his lot during his later years in England, and it is to Priestley's everlasting credit that he did not allow these untoward circumstances to disturb his serene and genial temper. In paying tribute to such a man-one whom Frederic Harrison has described as "the hero of the eighteenth century "--the citizens of Birstall have done honour to themselves. J. C. P.

\section{THE PROPOSED MEMORIAL TO LORD LISTER.}

Meeting at the Mansion House,

I $T$ may be said that the life of a great man needs 1 no permanent memorial from his contemporarics, and to some extent this is true. Poets, men of letters, and philosophers speak to posterity in their writings, statesmen and warriors have their deeds recorded in history, artists, sculptors, and architects have erected their own monuments which everyone may see. Yet even to them their fellow-men delight to raise some special token of their admiration. But there are others whose work is of a less public character, less obvious to the ordinary observer, and less easily understood, but which often has a more important effect upon the welfare of the world. Of such are the men of science, whose atmosphere is different from that of their fellow-men, and who occupy the edita doctrina sapientum templa serena. It is fitting that some permanent memorial should from year to year recall the names of such and remind those who come after of what it is that they have accomplished.

The great meeting which, under the auspices of the venerable Lord Mayor, himself a member of the medical profession, assembled at the Mansion House last week to sanction the project for raising a memorial, or rather some memorials, to Lord Lister, will, we are confident, meet with the approval of everyone, in all parts of the world. The names of those who attended the meeting and those who sent messages of regret at being unable to do so, indicate how wide is the sympathy that it has aroused. Statesmen, ecclesiastics, soldiers, representatives of science and of medicine, of the City companies, of hospitals, and of the general public were all enthusiastic in their commendation of the scheme. Such evidence reminds us that Lister's work was not merely one which revolutionised surgical practice, and was thus instrumental in saving his fellow-creatures from premature death and unnecessary suffering, and enabled the art of surgery to advance No. 2244, vOL. 90] by leaps and bounds to a degree undreamt of before; but that its scientific value alone is so great as to justify his being placed amongst the most distinguished men of this or any other age.

The Lord Chancellor, in the unavoidable absence of the Prime Minister, paid an eloquent tribute to Lister's pre-eminence and to the far-reaching effects of his doctrines; yet the man in the street has but little notion of the benefits he has derived from them; he has perhaps learned the two words "antiseptic system," but they convey no meaning to him; and he does not appreciate the dangers which have been averted and the sorrows prevented for him and those who are dearest to him. It is for these that a speaking memorial should be raised, and it is from these, if they can be made to understand its meaning, that we feel sure an appeal for the necessary funds will not be made in vain.

A very influential committee has been formed of representatives of all classes in the United Kingdom and the Colonies and of Ambassadors and Ministers of foreign countries, and in their opinion it is fitting that whatever is done should partake not only of a national, but an international character. This committee, after careful consideration, submitted a scheme to the Mansion House meeting, which met with cordial approval.

The Dean of Westminster, who is a warm sympathiser with it, desired that Lord Lister's ashes should find their final resting-place in Westminster Abbey, but owing to his own very strict injunctions concerning his funeral, this could not be carried out. It is proposed, therefore, that a medallion with a suitable inscription should be placed in the north aisle near those of Darwin and other eminent men of science that cluster round the monument of Newton. Westminster Abbey is an international institution, and it is certain that this proposal will not appeal to Englishmen alone.

It is also thought that everyone will be in favour of the erection of a sculptured monument, not a mere statue, but something which will direct attention to the nature of his achievements, in some prominent place in London which every citizen and every visitor cannot fail to see and to observe.

But it was felt that a memorial of a still more international character was desirable, and for that the committee recommended something which would combine the merits of the Nobel Prize and those of the Carnegie Trust. Under the proposed scheme the trustees of the fund would be able to devote the interest of it at their discretion either to the promotion of research bearing upon the progress of surgery, or as awards in recognition of notable advances in this science. Naturally these awards would be open to men of all nations, and this is as it should be, for Lister's work was not in any sense insular; its beneficent effects are felt in every part of the inhabited world.

We think that the decisions of the committee are wise and will meet with general approval. It is needless to say that in order to carry them out a large sum of money will be required. We are happy to hear that already several generous donations have been made, and we have great 
confidence that the appeal will be widely responded to. We would point out that it is not only the large gifts of the wealthy that are sought, though they are no doubt essential to the success of the scheme, but also the smaller tributes of esteem, the thank-offerings of those who recognise that every household in the land is a debtor to the great man who has passed from amongst us.

Donations should be sent to the treasurers of the Lister Memorial Fund, Royal Society, Burlington House, W.

\section{LECOQ DE BOISBAUDRAN.'}

$\mathrm{N}$ the death of $\mathrm{M}$. Lecoq de Boisbaudran, which 1 took place in May of the present year, there passed from the field of activity one of the most brilliant and energetic of French investigators. Lecoq de Boisbaudran was an amateur in the true sense of the word, and he had the faculty of concentrating the whole of his energy upon the question of the moment. He was born in Cognac in 1838 . His parents were of noble family in Poitou, but their circumstances prevented his receiving more than an ordinary education. While a young man, he studied mathematics under his uncle, who had been a student at l'École Polytechnique, but his interest quickly became absorbed in the science of chemistry; he eventually succeeded in gaining an entrance to the laboratory of Würtz at l'École de Médecine, and it was here that he made the discovery of the element gallium.

Among his earlier contributions to science are papers on gravitation, meteorological phenomena, and also upon matters connected with agriculture; but physical chemistry and spectroscopy received the greater share of his attention. The probable existence of gallium had bee foretold by Mendeléeff, who had proposed the name ekaaluminium, but to Lecoq de Boisbaudran belongs the honour of the discovery and the isolation of the element. In the field of spectroscopic research his name may be classed with those of Kirchhoff, Bunsen, Sir G. G. Stokes, and Sir William Crookes, as one of the founders of the science of spectrochemistry. His "Spectres Lumineux," published in 1874, was one of the most perfect works on spectroscopy at that time, and it possesses considerable value even at the present day; although limited to the visible region, the drawings are marvellously exact, and in the index wave-lengths of all the lines in the fifty-six spectra shown are given in Angström units to one place of decimals; the labour involved in the work was enormous.

At the time when Lecoq de Boisbaudran was in the prime of his scientific activity, the chemistry $f$ the rare earths was receiving considerable attention. Clève of Upsala, Marignac, Demarcay, Crookes and others were hard at work in that very interesting field of research, and he devoted himself with all the energy of his nature to the

1 An article from the pen of M. G. Urhain upon the life and work of Iecoo de Boishaudran appeared in the Rerne Génerale des Sciences for September 15, and to that the present writer is indebted for several particulars not other wise a vailable. work; during the period from 1880 to 1900 his communications to the Academy appeared in almost every issue of the Comptes rendus. He was successful in discovering and isolating the elements samarium and dysprosium, and he very completely investigated the body now known as gadolinium, which had been provisionally named $\mathrm{Y}$ a by Marignac.

In his earlier investigations he depended largely upon the indications given by the spark spectrum, produced by passing an alternating spark between electrodes immersed in a solution of the salts, and also upon the absorption spectrum of the solution; the spectra of didymium, erbium, holmium, \&c., were very fully examined by this latter method.

At the time when the work of Sir William Crookes upon the kathode phosphorescence spectrum of the rare earths was published, he made the observation that if the condensed spark from one electrode was allowed to strike upon the surface of a liquid containing a rare earth salt, there was produced, just where the discharge struck, a faint luminous spot, which, when examined with a spectroscope of low power, gave rise to a series of faintly luminous bands, closely resembling the phosphorescent bands of Crookes; this he called the reversal spectrum, and the method of investigation was largely used by him in his speculations upon the constitution of the yttria earths. His conclusions in this particular were in direct opposition to those of Crookes, who, as the result of an extended series of observations on the brilliant bands produced by kathode phosphorescence, had suggested that the element yttrium was composed of a number of very closely allied bodies, which he termed meta-elements, each producing a distinct phosphorescent spectrum. M. de Boisbaudran, on the other hand, held the opinion that yttria, when perfectly pure, did not phosphoresce under kathode rays, and that the bands observed by Crookes were due to impurities contained in the yttria.

The origin of the band-producing earths is by no means clear even at the present day, but the fact remains that although much work has been since done upon the element yttria, no one has succeeded in producing the non-phosphorescing material of Lecoq de Boisbaudran. It is a great misfortune that the numerous researches of Lecoq de Boisbaudran, particularly those referring to the rare earths, have not been collected together and published in complete form; there are probably few of the rare earth elements about which some observation could not be found under his name; but, scattered as they are in isolated papers, they are in large measure lost, and probably many of his original observations will have to be re-made by his successors. This, unfortunately, was characteristic of the man. His method was to work and publish almost simultaneously; so engrossed was he in his work that he cared little for public recognition.

The crcss of the Legion of Honour was conferred upon him for his discovery of the element gallium, but he never officially received the Order. 